\title{
POLITI- OG IKKE-POLITIANMELDT VOLDTÆGT OG VOLDTÆGTSFORSØG I \&̊RHUS AMT I PERIODEN 1. NOVEMBER 1999 - 1. NOVEMBER 2000
}

Af vicestatsobducent, dr.med. Annie Vesterby Charles, Afdelingslæge, PH.D. Ole BRINK OG LEKTOR, PH.D. JyTTE BANNER

The first Danish rape crisis centre was established November 1st, 1999, in the County of Aarhus, Denmark. It is open day and night to victims of both rape and attempted rape, regardless of whether the alleged crime was reported to the police. The current study seeks to evaluate the extent and character of rape within the County of Aarhus, which has 640,000 inhabitants (12\% of the Danish population). Data on rapes and attempted rapes committed between November 1, 1999, and November 1, 2000, were collected from files concerning victims who had either been seen by a doctor at the Rape Crisis Centre or reported an incident to the local police, or both. This database yielded 58 victim-cases for analysis.

Ten (17\%) of these victims reported their victimisation to the Rape Crisis Centre only, while $18(31 \%)$ reported to police only, and $30(52 \%)$ reported to both the Rape Crisis Centre and to the police. Four (29\%) of 14 women who contacted the Rape Crisis Centre directly without prior reporting to the police decided to involve the police within one month of the incident.

No obvious differences could be found between cases reported and those not reported to the police. Looking at all 58 victimisations, $40 \%$ were "stranger rape", $47 \%$ "date rape" and 13\% "partner rape". Out of 48 cases reported to the police police, five were rejected as false accusations and one was reclassified as indecent behaviour. Eight perpetrators were convicted. *

Det reelle omfang af voldtægt og voldtægtsfors $\emptyset$ g er ikke kendt (1). Ifølge politiets årsberetning (2) blev der i 2000 anmeldt 497 tilfælde af voldtægt og voldtægtsfors $\varnothing \mathrm{g}(\S \S 216,217,221) \bmod 477$ året forinden. If $\varnothing l g e$ en nylig afsluttet dansk undersøgelse (3) angiver 2,6\% af kvinder og $1 \%$ af mænd at have været offer for voldtægt eller voldtægtsfors $\emptyset$.

Første november 1999 åbnede landets første "Center for Voldtægtsofre" i Århus Amt. Dette center er en døgnåben modtagelse, hvortil ofre kan henvende sig uden forudgående politianmeldelse. Centeret foretager akutte retslægelige undersøgelser - med dokumentation og sporsikring - af ofre der allerede har

* Title in English: Rapes and Attempted Rapes Reported and Not-Reported to the Police in Aarhus County, Denmark: November 1, 1999-November 1, 2000. Original in Danish. 
anmeldt overgrebet til politiet, men også af ofre der ikke ønsker politianmeldelse.

Formålet med dette arbejde er at redegøre for omfang og karakter af voldtægt og voldtægtsforsøg i Århus Amt i en étårig periode, som er det første år efter åbningen af "Center for Voldtægtsofre", Århus Amt.

\section{Materiale og metoder}

Materialet omfatter alle ofre for voldtægt og voldtægtsfors $ø$ g fra Århus Amt undersøgt ved "Center for Voldtægtsofre", Århus Amt, eller på Retsmedicinsk Institut, Aarhus Universitet, i perioden 1. november 1999 til 1. november 2000 samt ofre, som i samme tidsperiode foretog politianmeldelse til en af amtets politikredse, men hvor der ikke forelå en retslægelig undersøgelse. De ofre som efterfølgende viste sig at have indgivet falsk anmeldelse er inkluderet i materialet.

Der blev foretaget en registrering af anmeldelses- og undersøgelsestidspunkt, overgrebets karakter, offerets alder og køn, forekomst af skader hos offeret, gerningssted, evt. alkoholpåvirkethed hos offer eller gerningsmand samt sagernes udfald hos politiet og retten.

Justitsministeriet har givet tilladelse til gennemgang af rapportmaterialet.

\section{Resultater}

I den ét-årige undersøgelsesperiode blev der registreret 58 tilfælde af voldtægt og voldtægtsforsøg ved "Center for Voldtægtsofre" og politiet i Århus Amt. Heraf var 18 ofre alene registreret hos politiet (Grenå politikreds to sager, Odder politikreds tre sager, Silkeborg politikreds fire sager, Århus politikreds fire sager og Randers politikreds fem sager).

Af de 40 ofre registreret ved "Center for Voldtægtsofre" blev 26 undersøgt på anmodning fra politiet efter politianmeldelse. De resterende 14 ofre ville ikke politianmelde angrebet, men hovedparten - 12 - ønskede alligevel en retslægelig undersøgelse med sporsikring og dokumentation. Fire af de 14 foretog da også senere i forløbet politianmeldelse, mens de resterende 10 fastholdt ønsket om ikke at anmelde overgrebet til politiet.

Overgrebets karakter, gerningssted og sagernes udfald for samtlige 58 registrerede tilfælde fremgår af oversigten i tabel 1-4.

Tabel 1. Voldtægtens karakter

\begin{tabular}{|l|c|c|c|}
\hline & $\begin{array}{c}\text { A } \\
\text { Alene kendt af } \\
\text { Politiet }\end{array}$ & $\begin{array}{c}\text { B } \\
\text { Alene kendt af "Center for } \\
\text { Voldtægtsofre" } \\
\text { (ikke politianmeldt) }\end{array}$ & $\begin{array}{c}\text { C } \\
\text { Kendt af både politi og } \\
\text { "Center for Voldtægtsofre" }\end{array}$ \\
\hline Overfaldsvoldtægt & 10 & 3 & 10 \\
\hline Kontaktvoldtægt & 6 & 6 & 14 \\
\hline Parvoldtægt & 1 & 1 & 6 \\
\hline Uoplyst & 1 & 10 & 30 \\
\hline Ialt & 18 & 10 & \\
\hline
\end{tabular}


Voldtægtens karakter er defineret som af Britta Kyvsgaard (4), hvor parvoldtagt defineres som voldtægt mod nuværende seksuel partner og mod tidligere seksuel partner, såfremt forholdet er ophørt inden for et kortere tidsrum forud for voldtægten. Kontaktvoldtagt er tilfælde, hvor parterne umiddelbart forinden har været sammen på en måde, som kunne være optakt til en seksuel kontakt. Omfatter også de tilfælde, hvor parterne kender hinanden i forvejen, f.eks. naboer og kollegaer. Overfaldsvoldtagt er de tilfælde, hvor gerningsmanden slet ikke kender eller kun har et yderst perifert kendskab til offeret, og hvor der ikke forud for voldtægten har været et samvær, som kan karakteriseres som kontaktvoldtægt.

Alle de registrerede sager vedrører kvinder.

\section{A. Politianmeldte sager uden retslægelig undersøgelse}

Gennemsnitsalderen for de 18, der alene var registreret hos politiet, var 22 år (spredning 14-41 år). Elleve anmeldte overgrebet inden for et døgn, medens de resterende syv anmeldte mere end to døgn senere.

Det drejer sig om forskellige sager, hvor kvinderne ifølge deres forklaring var blevet grebet fat i og væltet omkuld - evt. fået en del af beklædningen revet af, var blevet befølt eller berørt i skridtet - og i tre tilfælde blev der angivet vaginalt samleje.

\section{B. Ikke-politianmeldte sager}

Gennemsnitsalderen for de kvinder, som ikke ønskede at foretage politianmeldelse var 22 år (spredning 13-43 år). Seks ofre henvendte sig til "Center for Voldtægtsofre" mindre end ét døgn efter overgrebet og to efter mindre end tre døgn (henholdsvis 46 og 52 timer senere). To ofre havde alene kontakt og samtale med sygeplejerske og læge, men ville ikke have foretaget retslægelig undersøgelse eller politianmeldelse af overgrebet af frygt for repressalier.

Overgrebene er beskrevet som sager, hvor ofrene i beruset tilstand mente eller troede at have været udsat for samleje, at de var blevet truet eller presset til seksuelt samvær, evt. med samleje.

Én var blevet forfulgt af en ukendt og væltet omkuld.

\section{Politianmeldte sager med retslægelig undersøgelse af ofrene}

Gennemsnitsalderen for de 30 ofre, som var registreret hos både politiet og på "Center for Voldtægtsofre" var 25 år (spredning 13-81 år). Nitten anmeldte forholdet mindre end et døgn efter overgrebet og otte mere end to døgn senere.

Den retslægelige undersøgelse blev i 19 tilfælde foretaget mindre end et døgn efter overgrebet og i otte tilfælde mere end to døgn senere (fra 3 til 31 døgn senere).

Overgrebene havde karakter af, at gerningsmanden tiltvang sig samleje med et beruset offer, eller at offeret vågnede ved, at gerningsmanden var i færd med at forgribe sig på offeret, at en forudgående kontakt med efterfølgende invitati- 
on til besøg i hjemmet udviklede sig til et overgreb, at offeret af samleveren blev tvunget til samleje, at gerningsmanden brød eller trængte ind i offerets bolig, at offeret blev kidnappet, holdt indespærret og voldtaget, at offeret blev overfaldet eller slået ned uden for hjemmet, at offeret blev forfulgt eller lukket inde på et toilet og her tvunget til sex, eller at offeret blev tvunget til samleje med flere gerningsmænd.

Tabel 2. Fysiske skader beskrevet hos offeret

\begin{tabular}{|l|c|c|c|}
\hline & $\begin{array}{c}\text { A } \\
\text { Alene kendt af } \\
\text { politiet }\end{array}$ & $\begin{array}{c}\text { B } \\
\text { Alene kendt af "Center for } \\
\text { Voldtægtsofre" }\end{array}$ & $\begin{array}{c}\text { C } \\
\text { Kendt af både politi og } \\
\text { "Center for Voldtægtsofre" }\end{array}$ \\
\hline $\begin{array}{l}\text { Skader på ydre } \\
\text { kønsorganer }\end{array}$ & 0 & 0 & 5 \\
\hline $\begin{array}{l}\text { Skader andre steder } \\
\text { på kroppen, ansigt } \\
\text { eller lemmer }\end{array}$ & 2 & 4 & 19 \\
\hline
\end{tabular}

Mere end halvdelen af ofrene - 19 - i de politianmeldte sager (C) havde ved lægeundersøgelsen mindre læsioner i hovedet, på krop eller lemmer (Tabel 2).

Ingen ofre havde læsioner, som krævede lægebehandling eller indlæggelse, og ingen havde læsioner eller forandringer i mundhule eller endetarmsåbning.

Fire ofre blev på undersøgelsestidspunktet fundet klinisk alkoholpåvirkede, og i 11 tilfælde angav offeret, at gerningsmanden havde været alkoholpåvirket på tidspunktet for overgrebet.

En stor del af overgrebene fandt sted på offerets eller gerningsmandens bopæl eller i anden privat bolig (tabel 3).

Tabel 3. Gerningssted

\begin{tabular}{|l|c|c|c|}
\hline & $\begin{array}{c}\text { A } \\
\text { Alene kendt af } \\
\text { politiet }\end{array}$ & $\begin{array}{c}\text { B } \\
\text { Alene kendt af "Center for } \\
\text { Voldtægtsofre" }\end{array}$ & $\begin{array}{c}\text { C } \\
\text { Kendt af både politi og } \\
\text { "Center for voldtægtsofre" }\end{array}$ \\
\hline Udendørs & 9 & 5 & 4 \\
\hline Offentligt sted & 1 & 1 & 7 \\
\hline $\begin{array}{l}\text { Arbejdsplads } \\
\text { Offer }\end{array}$ & 1 & & \\
\hline $\begin{array}{l}\text { Arbejdsplads } \\
\text { Gerningsmand }\end{array}$ & 2 & & 9 \\
\hline $\begin{array}{l}\text { Bopæl } \\
\text { Offer }\end{array}$ & 3 & 1 & 7 \\
\hline $\begin{array}{l}\text { Bopæl } \\
\text { Gerningsmand }\end{array}$ & 2 & 3 & 3 \\
\hline Anden privat bolig & & 10 & 30 \\
\hline I alt & 18 & & \\
\hline
\end{tabular}


I otte sager var der mere end én gerningsmand; fem af disse sager var alene registreret på "Center for Voldtægtsofre" og ikke anmeldt til politiet.

Af de 48 sager, som blev anmeldt til politiet, blev der afsagt dom i ni sager (Tabel 4).

Der var fem falske anmeldelser.

Tabel 4. Sagens udfald

\begin{tabular}{|l|c|c|}
\hline & $\begin{array}{c}\text { A } \\
\text { Alene kendt af politiet }\end{array}$ & $\begin{array}{c}\text { C } \\
\text { Kendt af både politi og } \\
\text { "Center for Voldtægtsofre" }\end{array}$ \\
\hline Sagen stillet i bero & 8 & 3 \\
\hline Påtale opgivet & 6 & 17 \\
\hline Dom afsagt*** & $2^{*}$ & $7^{* *}$ \\
\hline Falsk anmeldelse & 2 & 3 \\
\hline
\end{tabular}

I én sag blev der afsagt dom ved underretten; dommen blev senere anket, og sagen er endnu ikke afsluttet. I en anden sag blev der senere rejst sigtelse for blodskamsforhold.

** Fire erkendte (heraf én delvist), mens tre nægtede (i én af disse sager var der flere sigtede, som alle nægtede, at samleje havde fundet sted under tvang).

*** I de otte politianmeldte sager, hvori der er afsagt endelig dom, lyder dommene på henholdsvis: Forvaringsdom, to års fængsel, ni måneder, otte måneder, seks måneder, seks måneder og 30 dages fængsel; i sidstnævnte tilfælde erkendte sigtede beføling i skridtet.

De falske anmeldelser vedrørte tre påståede overfaldsvoldtægter, én kontaktog én parvoldtægt, begge på offerets bopæl.

\section{Diskussion}

I 2000 var der ifølge politiets årsberetning 60 politianmeldelser vedrørende voldtægt og voldtægtsforsøg i Århus Amt - svarende til en incidens på $9,4 / 100.000$ pr. år. Dette er i overensstemmelse med landsgennemsnittet (9,3/100.000 pr. år) med 497 anmeldelser i hele Danmark (5.530.000 indbyggere i år 2000). Der er således grund til at antage, at det observerede mønster for voldtægt og voldtægtsforsøg i Århus Amt ikke afviger fra det øvrige Danmark.

Den foreliggende undersøgelse har haft som sit hovedformål at afdække, om politiets registreringer af voldtægt og voldtægtsforsøg giver et reelt billede af omfanget og karakteren af disse forbrydelser i et veldefineret geografisk område som Århus Amt med 640.000 indbyggere (12\% af den danske befolkning i år 2000). Muligheden for at vurdere dette forelå med indvielsen af landets første døgnåbne modtagelse for ofre for voldtægt og voldtægtsforsøg pr. 1. november 1999 (5).

Undersøgelsen, som inkluderer såvel politianmeldte som ikke-politianmeldte sager vedrørende voldtægt og voldtægtsforsøg, må anses for at give et mere realistisk billede af omfanget af voldtægt og voldtægtsforsøg i Århus Amt, end politiets statistikker er udtryk for.

Undersøgelsen viste således, at 10 eller hver fjerde af de kvinder, der henvendte sig ved "Center for Voldtægtsofre", ikke ønskede at foretage politianmel- 
delse, og at nogle (10\%) først anmelder efter en vis betænkningstid. Undersøgelsen viser også, at fem kvinder $(10 \%)$ havde foretaget falsk anmeldelse, hvilket ikke bliver korrigeret i politiets årsopgørelser over antallet af anmeldte sager.

Det er dog ikke muligt alene på grundlag af undersøgelsen her at angive størrelsen af mørketallet for voldtægt og voldtægtsforsøg; at det er større end det, der kommer frem ved at supplere politiets statistikker med tallet for ikkepolitianmeldte sager ved "Center for Voldtægtsofre", er der næppe tvivl om. Det fremgår f.eks. af centerets årsberetning (6), at der er en række henvendelser, som alene er af telefonisk karakter eller personlige samtaler med sygeplejerske - det vil sige tilfælde, som kan være ikke-registreret voldtægt eller voldtægtsforsøg. Hvorvidt dette er tilfældet eller ej kan dog ikke afgøres, før der foreligger en nærmere undersøgelse af disse henvendelser.

Når der ses bort fra de falske anmeldelser, var der 21 (40\%) af samtlige registrerede, der var overfaldsvoldtægter, 25 (47\%) var kontaktvoldtægter, og 7 $(13 \%)$ var parvoldtægter.

De tilsvarende tal for Københavns Politikreds i $1990-92$ var $54 \%$ for overfaldsvoldtægter, $36 \%$ for kontaktvoldtægter og $10 \%$ for parvoldtægter (1).

Tallene i Århus Amt er endnu for små til at sige noget sikkert om forskellen i karakteren af voldtægt og voldtægtsforsøg på de politianmeldte og de ikke-politianmeldte sager, og om tendensen holder med flere registrerede kontaktvoldtægter end overfaldsvoldtægter.

Undersøgelsen viser også, at 31\% af de registrerede sager alene var kendt af politiet.

Det kan undre, at politiet ikke finder grundlag for en retslægelig undersøgelse i disse tilfælde, selv når forholdet anmeldes kort tid efter overgrebet - også selv om der ikke på anmeldelsestidspunktet er oplysning om samleje.

Formålet med den retslægelige undersøgelse er ikke alene sikring af sædprøver, men en fuldstændig undersøgelse af et formodet offer med beskrivelse af ydre beklædning, beskrivelse af offeret og eventuelle læsioner og tilsmudsninger samt at bistå politiet med sikring af offerets beklædning. Dette er forhold ved undersøgelsen, som kan bidrage til at afkræfte eller understøtte offerets forklaring og eventuelt pege på en gerningsmand.

Et af centerets tilbud er, at ofrene kan henvende sig uden forudgående politianmeldelse og på centeret få foretaget retslægelig undersøgelse med dokumentation og sporsikring til brug for en evt. senere politianmeldelse. Fire ofre tog imod dette tilbud; alle disse sager blev dog afsluttet uden på- eller tiltale og ikke ført for retten.

I de sager, der er politianmeldt, og som senere førte til domfældelse, viser gennemgangen af sagsakterne, at resultatet af de retslægelige undersøgelser næppe har tjent som bevis eller dokumentation for voldtægt eller voldtægtsforsøg. 
Hovedindtrykket er, at der fortsat lægges størst vægt på offerets og sigtedes troværdighed og i mindre grad på resultatet af den retslægelige undersøgelse, hvilket også understøttes af et tidligere mindre arbejde fra Retsmedicinsk Institut i Århus (7). Om dette er udtryk for manglende viden eller indsigt hos politi og anklagemyndighed, med hensyn til hvorledes undersøgelsesresultaterne skal tolkes og bruges, eller om det er udtryk for, at den retslægelige undersøgelse kun sjældent kan dokumentere offerets forklaring om voldtægt eller voldtægtsforsøg, er det for tidligt at udtale sig om.

Undersøgelsen har vist, at der er en underrapportering i politiets statistikker af omfanget af voldtægt og voldtægtsforsøg, og at hver fjerde kvinde ikke ønsker at foretage politianmeldelse. Om denne udvikling vil fortsætte i de kommende år, vil nøje blive fulgt og analyseret ved "Center for Voldtægtsofre" i Århus Amt i samarbejde med Retsmedicinsk Institut.

\section{Litteratur}

1. Voldtægters omfang og karakter I Danmark. En undersøgelse af voldtægtsanmeldelser i 1990, 1991 og 1992 \& Voldtægtsudviklingen i Danmark. Rigpolitichefen 1998

2. Politiets Årsberetning 2000: www.politi.dk

3. Elklit, A. Victimisation and PTSD in a Danish National Youth Sample. (Submitted)

4. Kyvsgaard, B. Udviklingen i strafudmålingsniveauet i voldtægtssager. 2001: www.jm.dk

5. Vesterby, A., Jensen, J., Hejl, B.L. Center for Voldtægtsofre, Skadestuen, Århus Amtssygehus. Medicus nr. 7, 10-11, 1999

6. Center for Voldtægtsofre, Skadestuen, Århus Amtssygehus. Årsrapport 2000

7. Eskildsen, L. Retslægelige erklæringer i voldtægtssager. Nordisk Rettsmedisin nr. 3, 61-76, 1999

Taksigelser

Politikredsene i Århus Amt takkes for velvillig hjælp

Adresser: Annie Vesterby Charles og Jytte Banner, Retsmedicinsk Institut, Århus Universitet, Finsensgade 15, 8000 Aarhus C.

Ole Brink, Ortopædkirurgisk Afdeling, Århus Amtssygehus, Århus Universitetshospital, Tage Hansens Gade 2, 8000 Århus C . 